\title{
First record of a victorellid Bryozoan (Gymnolaemata: Victorellidae) from the Iberian Peninsula
}

\author{
Juan Rueda ${ }^{1, *}$, Oscar Reverter-Gil ${ }^{2}$, Joan Miquel Benavent $^{3}$ and Javier Souto ${ }^{2,4}$ \\ ${ }^{1}$ Instituto Cavanilles de Biodiversidad y Biología Evolutiva, Universitat de València, 46100 Burjassot, Spain. \\ 2 Departamento de Zooloxía e Antropoloxía Física, Facultade de Bioloxía, Universidade de Santiago de \\ Compostela, 15782 Santiago de Compostela, Spain. \\ ${ }^{3}$ Servicio Devesa Albufera, Ayuntamiento de Valencia, Valencia, Spain. \\ ${ }^{4}$ Institut für Paläontologie, Fakultät für Geowissenschaften, Geographie und Astronomie, Geozentrum, Univer- \\ sität Wien, Althanstrasse 14, 1090, Wien, Austria. \\ * Corresponding author: juan.rueda@uv.es
}

Received: 23/03/2015 Accepted: 04/12/2015

\begin{abstract}
First record of a victorellid bryozoan (Gymnolaemata: Victorellidae) from the Iberian Peninsula

The discovery of new organisms in the Albufera Lake is an encouraging sign, considering the deterioration of this ecosystem. The finding of Victorella pavida on the shores of the Albufera Lake, which is a new record for the Iberian Peninsula, allows us to consider the fact that many invertebrate species are waiting for a quick and definitive recovery of the lake so they can take back the place that once belonged to them.
\end{abstract}

Key words: Victorella pavida, Victorellidae, Ctenostomata, albufera de València, Spain.

\section{RESUMEN}

Primera cita de un briozoo victorélido (Gymnolaemata: Victorellidae) para la Península Ibérica

La localización de nuevos organismos en el lago de l'Albufera es una señal esperanzadora frente al deterioro de este ecosistema. La desaparición de los macrófitos sumergidos entre los años 1960 y 70 provocó la eliminación de una fauna de invertebrados acuáticos de su lecho. El descubrimiento de Victorella pavida en el litoral de l'Albufera, como nueva cita para la Península Ibérica, nos permite pensar que numerosas especies de invertebrados están a la espera de una pronta y definitiva recuperación del lago para volver a ocupar el lugar que antaño les pertenecía.

Palabras clave: Victorella pavida, Victorellidae, Ctenostomata, albufera de València, España.

\section{INTRODUCTION}

The Albufera Lake is located south of Valencia and occupies 2800 hectares of the Natural Park. There is a littoral bar to the east that isolates the lake from the Mediterranean Sea. There is an important centre of population that is spread out along a chain of municipalities west of the lake. One of the major rice fields on the Iberian
Peninsula is located around the Albufera Lake. Since the 1970s, this aquatic system has suffered substantial degradation. Though it started as an oligo-mesotrophic lake from which water could be drunk, due to its numerous inner springs, it has become a hypereutrophic toxic lake due to the presence of cyanobacteria from the genera Planktothrix (Bradt \& Villena, 2002) and Microcystis (Romo et al., 2008). The aquatic vegeta- 
tion on the lake bed disappeared because of direct organic and industrial discharges. At the moment, vegetation only exists on the shoreline of the lake. It is for this reason that the project of an aquatic macroinvertebrates register was considered by the Valencia Town Council. During a unique campaign in July 2013, previously unrecorded species for this area were located, such as the new record of Cladocera Ilyocryptus agilis Kurz 1878 (Rueda et al., 2013) for the Iberian Peninsula or the new record for the province of Valencia of the Trichoptera Ecnomus tenellus (Rambur, 1842) (Rueda et al., 2014). Previous works on Rotifera (Arévalo, 1917a), Cladophora (Arévalo, 1916; 1917b), zooplankton in general (Arévalo, 1914), naiads (Haas, 1918), Coleoptera (Moróder, 1923; 1924), bivalve mollusks (Haas, 1924) and Porifera (Arndt, 1926), among others, shed light on the existing macroinvertebrate fauna in the waters of the Albufera Lake at the beginning of the 20th century. At that time, there were no recordings of bryozoa in the lake.

\section{METHODS}

Samples were taken from 19 points on the lake shore (Fig. 1); however, Bryozoa were only collected in AL04. This location corresponds to the end of an old ravine that used to receive numerous discharges. Currently, the situation is more controlled in this area. A first preliminary survey of the habitat was conducted before the sampling of aquatic invertebrates commenced at point AL04. Difficulties in sampling the shore line on foot made the use of a boat compulsory (Fig. 2). A hand-net with a $250 \mu \mathrm{m}$ mesh was used for this sampling. In the highly homogenous selected environments, ten searches using a 1-m hand net along a one-meter transect line were conducted. Every sub-sample was concentrated on a plastic tray of $30 \mathrm{~cm}$ by $40 \mathrm{~cm}$. Bryozoan colonies were present at a depth of $30-40 \mathrm{~cm}$ on pieces of dead reed among the roots that were growing out from the shore line. Along with the field samples from the Albufera Lake, the

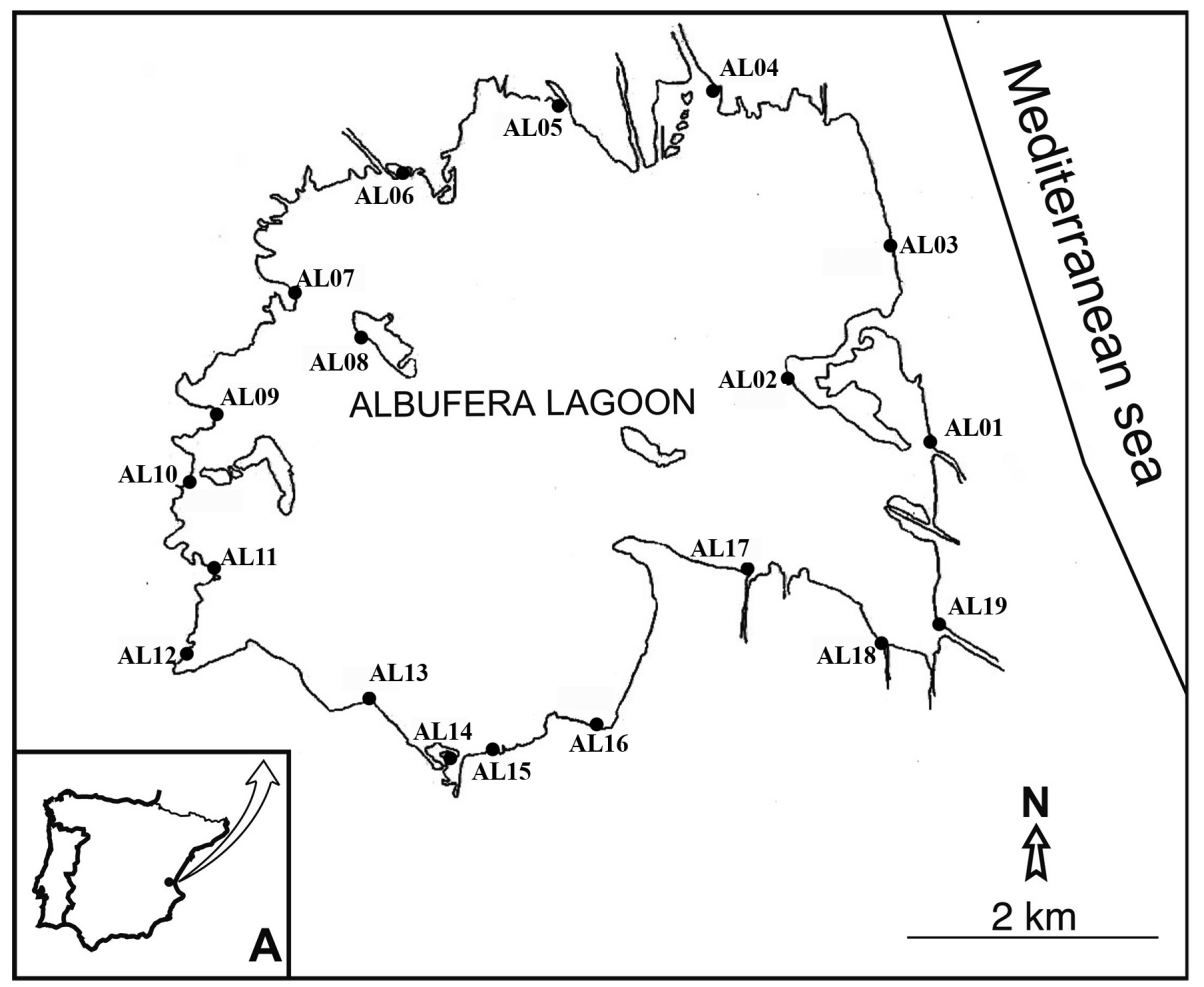

Figure 1. Location of sampling site in the Albufera lake, Valencia (A: Iberian Peninsula). Localización de los puntos de muestreo en la Albufera de Valencia (A: Península Ibérica). 
oxygen content, conductivity, salinity and water temperature were measured in situ using a multimeter WTW 330i (Table 1). Concurrently, we collected water samples for laboratory analyses of alkalinity and chloride. The bryozoan colonies were examined with a Leica MZ16 stereomicroscope and a Leica DM 2000 optical microscope. Photographs were taken with a Leica DFC 425 digital camera coupled to the optics, and measurements were taken directly on the photographs. Part of the samples were deposited in the Museo Nacional de Ciencias Naturales, Madrid (MNCN).

\section{RESULTS}

Phylum: BRYOZOA Ehrenberg, 1831

Class: GYMNOLAEMATA Allman, 1856 Order: CTENOSTOMATA Busk, 1852 Family: VICTORELLIDAE Hincks, 1880 Genus: Victorella Saville-Kent, 1870
Species: Victorella pavida Saville-Kent, 1870 (Fig. 3).

Victorella pavida Saville-Kent, 1870: 34, pl. 4; Hincks 1880: 561, pl. 79, figs. 4-7; Prenant \& Bobin 1956: 240, fig. 106 I-VIII; d'Hondt 1983: 53, figs. 27A, 28A; Hayward 1985: 96, figs. 30A, 31 .

\section{Material examined}

Site AL04, (UTM: 30 North, 729148mE, 4359978mN), 30-40 cm depth, 07/23/2013. Several colonies of bryozoan on pieces of dead reed close to the roots that grew out from the water.

\section{Description}

Colony encrusting, delicate and transparent, composed by elongate, cylindrical autozooids forming dense clumps. Autozooids composed by a slender proximal portion, usually very short

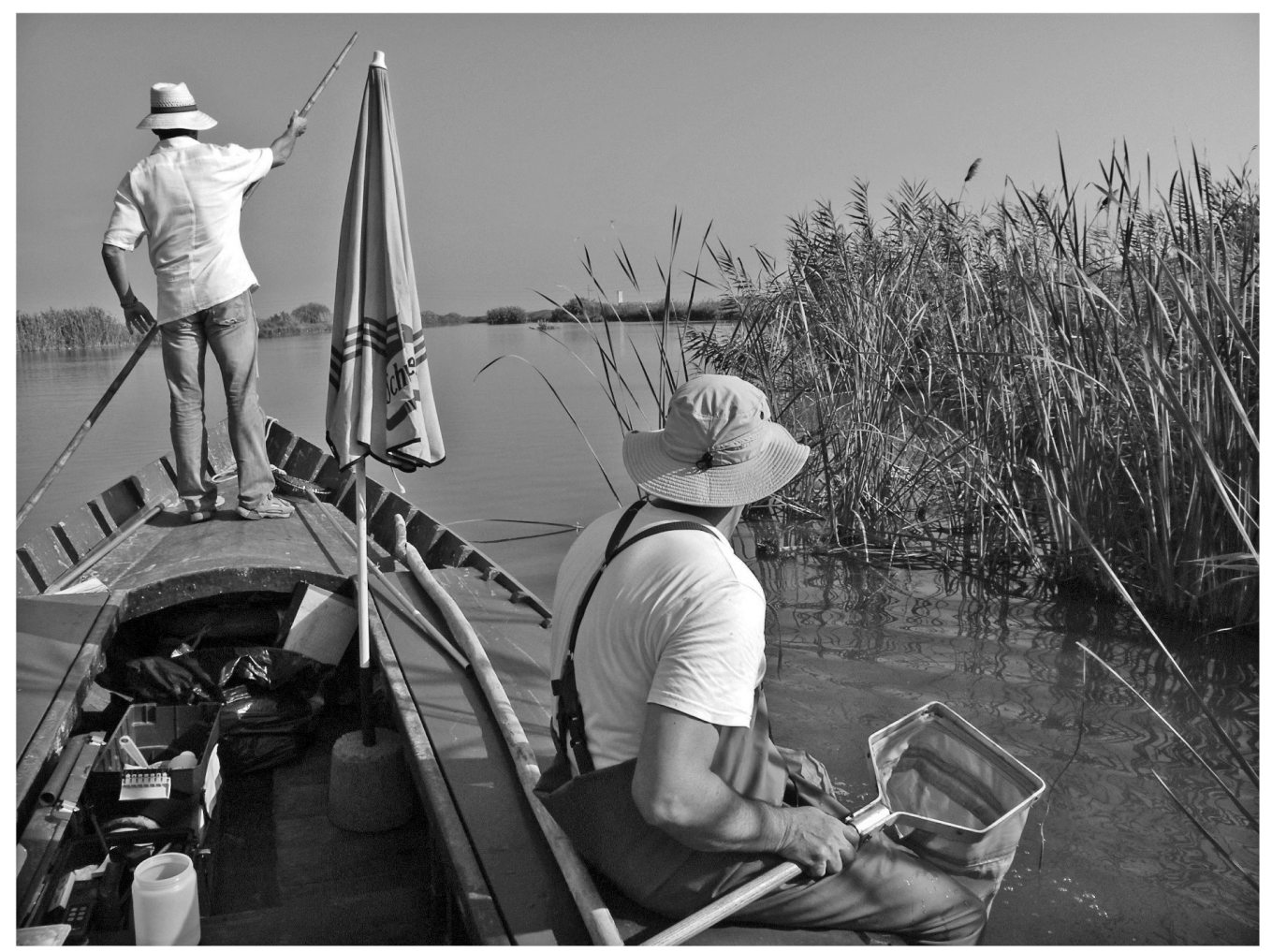

Figure 2. Sample site: AL04 (C. Molina). Estación de muestreo: AL04 (C. Molina). 
and thin, a short, adnate basal portion, slightly wider than the erect, long peristomial tube, $1.20-2.35 \mathrm{~mm}$ long by approximately $0.15 \mathrm{~mm}$ diameter, with its distal extreme quadrangular. Buds developed distally and laterally from the adnate basal portion of each autozooid or, typically, from the peristomial tube. In this case, the bud can give rise to new stolons or, if it is located more distally, to new autozooids, which can be divided again. Polypide with 8 tentacles. Gut elongate, with equal sized fore and hind cardia separated by a sphincter; caecal lobe about as long as the combined length of the cardia and foregut. Setae of the collar very long, jointed by a pleated, delicate membrane.

\section{Remarks}

Bryozoa are aquatic organisms that are normally colonial and largely marine. Approximately 6000 living species have been recognized. Among the three classes of the phylum, only the Phylactolaemata, with 74 species worldwide (Massard
\& Geimer, 2008), are entirely restricted to fresh water. The Stenolaemata are exclusively marine, whereas in the Gymnolaemata, the largest class (approx. 5200 species according to Gordon et al., 2009), most of the species are marine, and only a few of them live in brackish or fresh waters. The family Victorellidae Hincks, 1880 includes four genera and ten species of Gymnolaemate Ctenostomatous bryozoans (Bock \& Gordon, 2013), almost all of which are from brackish and fresh waters. None of these bryozoans were previously collected in the Iberian Peninsula. Victorella pavida is a species difficult to find, as well as to be identified as a bryozoan. This species was originally described in the brackish waters of the Victoria Docks in London (SavilleKent, 1870). It was later collected in many locations: the North Sea and the Baltic Sea, the Mediterranean Sea and the Black Sea, Brasil, the USA, India and Japan (Hayward, 1985). There is a previous record of the species near Spain, in Banyuls-sur-Mer (South of France), although according to Zabala (1986), this record

Table 1. UTM location, physical and chemical data of sampling sites. Localización UTM y valores de la físico-química de las muestras de agua.

\begin{tabular}{|c|c|c|c|c|c|c|c|c|}
\hline Sites & $\begin{array}{c}\text { UTM ETRS } 89 \\
30 \mathrm{~S}\end{array}$ & $\begin{array}{c}\text { Conductivity } \\
\mu \mathrm{S} / \mathrm{cm}\end{array}$ & $\begin{array}{c}\text { Salinity } \\
\mathrm{g} / \mathrm{L}\end{array}$ & $\begin{array}{c}\text { Oxygen } \\
\mathrm{mg} / \mathrm{L}\end{array}$ & $\begin{array}{c}\text { Temperature } \\
{ }^{\circ} \mathrm{C}\end{array}$ & $\mathrm{pH}$ & $\begin{array}{c}\text { Chloride } \\
\mathrm{mg} / \mathrm{L}\end{array}$ & $\begin{array}{c}\text { Alkalinity } \\
\mathrm{mmol} / \mathrm{L}\end{array}$ \\
\hline AL01 & $0731031 / 4356937$ & 2182 & 1.1 & 8.4 & 27.9 & 8.7 & 325 & 0.5 \\
\hline AL02 & $0729963 / 4357512$ & 2184 & 1.1 & 8.6 & 28.3 & 9.3 & 350 & 0.4 \\
\hline AL03 & $0730736 / 4358526$ & 2275 & 1.2 & 8.1 & 27.6 & 9.5 & 460 & 0.4 \\
\hline AL04 & $0729148 / 4359978$ & 2519 & 1.3 & 8.4 & 29.0 & 8.5 & 490 & 1.4 \\
\hline AL05 & $0727866 / 4359916$ & 2274 & 1.2 & 7.9 & 28.8 & 8.8 & 470 & 0.5 \\
\hline AL06 & $0726961 / 4359189$ & 2244 & 1.1 & 7.5 & 30.1 & 9.5 & 440 & 0.4 \\
\hline AL07 & $0725896 / 4358168$ & 2264 & 1.1 & 7.8 & 30.0 & 9.5 & 460 & 0.5 \\
\hline AL08 & $0726355 / 4358002$ & 2327 & 1.2 & 7.5 & 30.6 & 10.0 & 490 & 0.4 \\
\hline AL09 & $0725250 / 4357284$ & 2342 & 1.2 & 8.0 & 30.5 & 9.6 & 460 & 0.5 \\
\hline AL10 & $0725277 / 4356696$ & 2314 & 1.2 & 6.9 & 30.7 & 9.8 & 480 & 0.4 \\
\hline AL11 & $0725068 / 4355920$ & 1902 & 1.0 & 7.7 & 29.5 & 8.5 & 250 & 0.7 \\
\hline AL12 & $0725045 / 4355273$ & 2041 & 1.0 & 7.2 & 30.9 & 9.4 & 300 & 0.5 \\
\hline AL13 & $0726385 / 4354877$ & 1937 & 1.0 & 8.0 & 30.5 & 9.1 & 270 & 0.6 \\
\hline AL14 & $0727253 / 4354402$ & 1626 & 0.8 & 7.8 & 30.9 & 8.5 & 210 & 1.2 \\
\hline AL15 & $0727560 / 4354454$ & 2027 & 1.0 & 8.2 & 29.1 & 8.4 & 270 & 1.2 \\
\hline AL16 & $0728360 / 4354697$ & 1924 & 1.0 & 7.7 & 28.0 & 8.8 & 280 & 0.6 \\
\hline AL17 & $0729712 / 4355960$ & 1317 & 0.7 & 8.0 & 27.7 & 8.3 & 160 & 1.3 \\
\hline AL18 & $0730656 / 4355644$ & 2041 & 1.0 & 8.2 & 26.6 & 8.3 & 280 & 1.7 \\
\hline AL19 & $0731065 / 4355526$ & 2252 & 1.1 & 8.0 & 27.4 & 8.4 & 320 & 1.4 \\
\hline
\end{tabular}


is more likely to be a misidentification. Victorella pavida lives mainly in brackish waters, although there also several records in fresh waters. The colonies studied were collected in the location that had the highest salinity among the 19 points of sampling (Table 1). It was not collected from any other locality that had a lower level of salinity. Point AL04 corresponds to the end of a ravine that used to receive numerous discharges, although the situation is presently improved. The first sampling was conducted in July 2013, and colonies were collected in the following months.
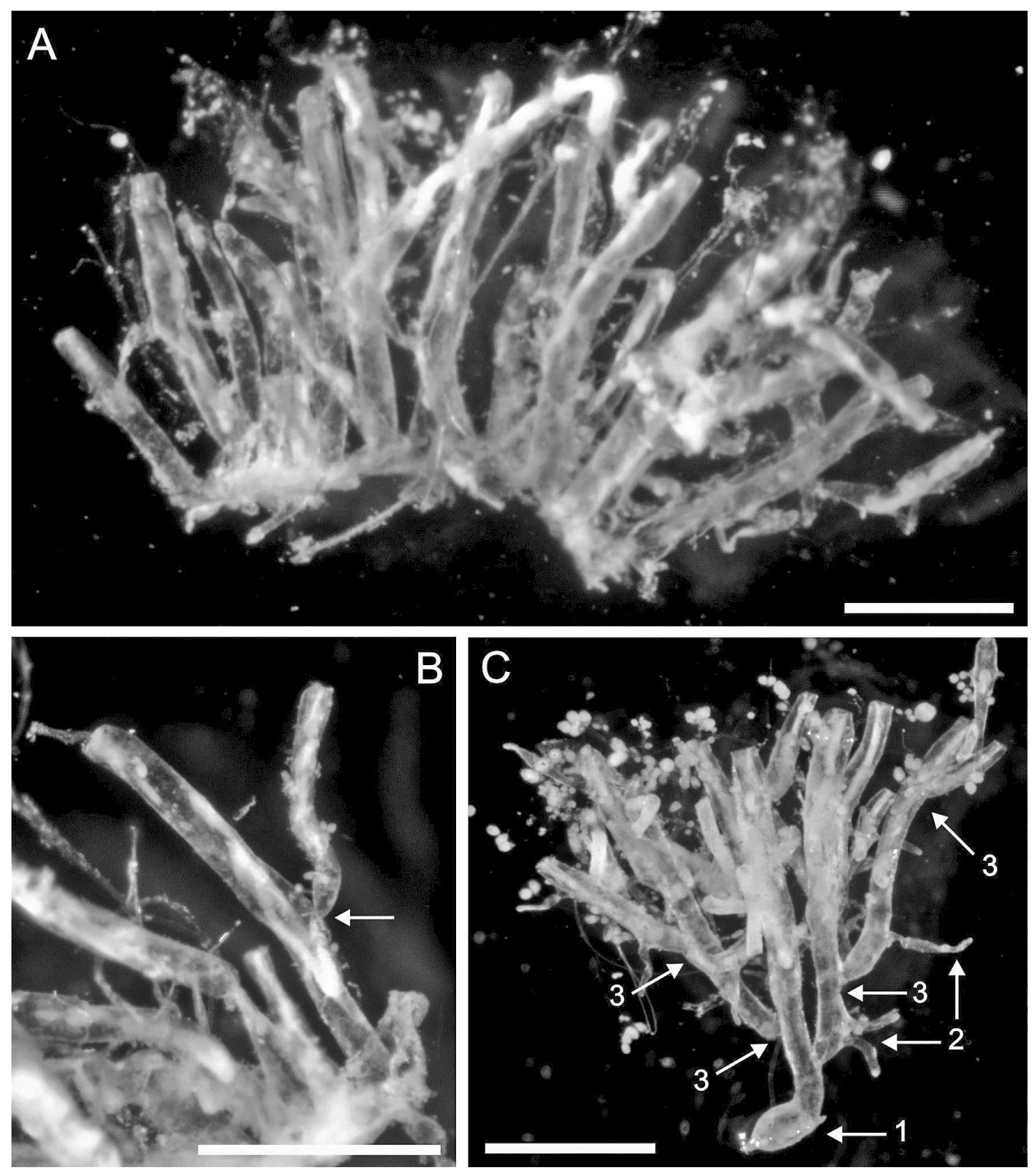

Figure 3. Victorella pavida Saville-Kent, 1870. (A) portion of a dense colony; (B) a young autozooid budded from the peristomial tube of maternal zooid (arrow: budding point); (C) portion of a colony originated from a single autozooid; note the basal adnate portion (1), the slender pseudostolons (2) and the successive peristomial buds (3). (scales: $1 \mathrm{~mm}$ ). Victorella pavida Saville-Kent, 1870. (A) porción de una densa colonia; (B) un joven autozooide creciendo sobre el tubo persitomial del autozooide materno (flecha: punto de gemación); (C) porción de una colonia, originada a partir de un único autozooide; a destacar la porción incrustante basal (1), los finos pseudoestolones (2) y los brotes peristomiales sucesivos (3). (escalas: $1 \mathrm{~mm}$ ). 
V. pavida is usually found with the hydroid Cordylophora and the phylactolaemate bryozoan Plumatella repens (see Hayward, 1985). The present material was found together with small colonies of an unidentified species of Plumatella, most likely Plumatella repens.

\section{ACKNOWLEDGEMENTS}

Thanks are due to Dr Eugenio Fernández-Pulpeiro - who passed away in September 2014for his dedicated commitment at the beginning of this study. This work was partially funded by the City of Valencia with JR (Ref: E-03602-2013-90 2013/11/06). The work by ORG and JS was partially supported by the project "Fauna Ibérica: Briozoos II (Familia Cribrilinidae-Familia Watersiporidae)" (CGL2010-22267-C07-02), cofinanced by the Ministerio de Economía y Competitividad (Spanish Government) and FEDER.

\section{REFERENCES}

ALLMAN, G. J. 1856. A monograph of the Freshwater Polyzoa, including all the known species, both British and Foreign. The Ray Society, London, UK.

ARÉVALO, C. 1914. El Laboratorio hidrobiológico del Instituto de Valencia. Boletín de la Real Sociedad Española de Historia Natural, 14(6): 338348.

ARÉVALO, C. 1916. Introducción al estudio de los cladóceros del plankton de la Albufera de Valencia. Anales del Instituto General y Técnico de Valencia, 1: 1-66.

ARÉVALO, C. 1917a. Algunos rotíferos planktónicos de la Albufera de Valencia. Anales del Instituto General y Técnico de Valencia, 2(8): 1-49.

ARÉVALO, C. 1917b. Cladóceros de la Albufera de Valencia. Boletín de la Sociedad Aragonesa de Ciencias Naturales, 16: 133-143 and 164-176.

ARNDT, W. 1926. Espongílidos del N y E de España recogidos por el Dr. F. Haas en los años 1914 a 1919. Anales del Instituto Nacional de Segunda Enseñanza de Valencia, 29: 1-9.

BOCK, P. E. \& D. P. GORDON. 2013. Phylum Bryozoa Ehrenberg, 1831. Zootaxa, 3703(1): 67-74.
BRADT, S. R. \& M. J. VILLENA. 2002. Detection of microcystins in La Albufera de Valencia (Spain) by an enzymelinked inmunoserbent assay (E.L.I.S.A). Limnetica, 20(2): 1-10.

BUSK, G. 1852. Catalogue of marine Polyzoa in the collection of the British Museum. I. Cheilostomata. Trustees of the British Museum (Natural History), London, UK.

EHRENBERG, C. G. 1831. Symbolae physicae, seu icones et descriptiones corporum naturalium novorum aut minus cognitorum, quae ex itineribus per Libyam, Aegyptum, Nubiam, Dongalam, Syriam, Arabiam et Habessiniam à P. C. Hemprich et C. G. Ehrenberg à studio annis 1820-25 redierunt à pars Zoologica, C.G. Ehrenberg, ed. Berolini., Animalia evertebrata exclusis Insectis. Vol. 4.

GORDON, D. P., P. D. TAYLOR \& F. P. BIGEY. 2009. Phylum Bryozoa. Moss animals, sea mats, lace corals. In: New Zealand Inventory of Biodiversity. Vol I. Animalia. Radiata, Lophotrochozoa, Deuterostomia. D. P. Gordon (ed.): 271-297. Canterbury University Press, Canterbury, UK.

HAAS, F. 1918. Las náyades de la Albufera de Valencia. Anales del Instituto General y Técnico de Valencia, 3: 1-68.

HAAS, F. 1924. Los moluscos de agua dulce de la Albufera de Valencia. Anales del Instituto General y Técnico de Valencia, 16: 1-17.

HAYWARD, P. J. 1985. Ctenostome Bryozoans. In: Synopses of the British Fauna (New Series). Vol. 33. D. M. Kermack \& R. S. K. Barnes (eds.). The Linnean Society of London and The Estuarine and Brackish-Waters Sciences Association. E. J. Brill/Dr. W. Backhuys. London, Leiden, Köln, Kobenhavn.

HINCKS, T. 1880. A History of the British Marine Polyzoa. Van Voorst, London, UK.

HONDT, J. L. d'. 1983. Tabular keys for the identification of the Recent Ctenostomatous Bryozoa. Mémoires de l' Institut Océanographique, 14: 1-134.

KURZ, W., 1878. Ueber limicole Cladoceren. Z. wiss. Zool. 30 (Suppl): 392-410.

MASSARD, J. A. \& G. GEIMER, 2008. Global diversity of bryozoans (Bryozoa or Ectoprocta) in freshwater. In: E. V. Balian, C. Lévèque, H. Segers \& K. Martens (eds): Freshwater animal diversity assessment. Hydrobiologia, 595(1): 93-99.

MORÓDER, E. 1923. Coleópteros del Lago de l'Albufera de Valencia. Boletín de la Real Sociedad Española de Historia Natural, 23: 70-73. 
MORÓDER, E. 1924. Los coleópteros del Lago y Dehesa de la Albufera de Valencia. Anales del Instituto General y Técnico de Valencia, 11: 1-22.

PRENANT, M. \& G. BOBIN. 1956. Bryozoaires, $1^{\text {er }}$ partie. Entoproctes, Phylactolèmes, Cténostomes. Faune de France, 60: 1-398.

RAMBUR, J. P. 1842. Histoire Naturelle des Insectes Névroptères. Septième Section, les trichoptères (Trichoptera). Paris.

ROMO, S., A. GARCÍA-MURCIA, M. J. VILLENA, V. SÁNCHEZ \& A. BALLESTER. 2008. Tendencias del fitoplancton en el lago de la Albufera de Valencia e implicaciones para su ecología, gestión y recuperación. Limnetica, 27(1): 11-28.

RUEDA, J., D. BORONAT, C. MOLINA \& J. M. BE-
NAVENT. 2013. Primera cita de Ilyocryptus agilis Kurz, 1878 (Cladocera: Anomopoda: Ilyocryptidae) en la Península Ibérica. Boletín de la Sociedad Entomológica Aragonesa. 53: 211-212.

RUEDA, J., C. MOLINA \& J. M. BENAVENT. 2014. Primeras citas de Ecnomus tenellus (Rambur, 1842) (Trichoptera: Ecnomidae) para las provincias de Castellón, Cuenca y Valencia (Este de España). Anales de Biología. 36: 1-3.

SAVILLE-KENT, W. 1870. On a new polyzoon, Victorella pavida, from the Victoria Docks. Quarterly Journal of Microscopical Science, 10(2): 35-39.

ZABALA, M. 1986. Fauna dels Briozous dels Països Catalans. Institut d'Estudis Catalans. Arxius de la Secció de Ciències, 84: 1-833. 
